Article

\title{
Mapping Entrepreneurs' Orientation towards Sustainability in Interaction versus Network Marketing Practices
}

\author{
Elena-Mădălina Vătămănescu ${ }^{1}$, Patrizia Gazzola ${ }^{2, *} \mathbb{1}$, , Violeta Mihaela Dincă ${ }^{3}$ and \\ Roberta Pezzetti ${ }^{2}$ \\ 1 Faculty of Management, National University of Political Studies and Public Administration, \\ 012104 Bucharest, Romania; madalina.vatamanescu@facultateademanagement.ro \\ 2 Department of Economics, University of Insubria, 21100 Varese, Italy; robertarita.pezzetti@uninsubria.it \\ 3 Faculty of Business Administration, in foreign languages, Bucharest University of Economics, \\ 010374 Bucharest, Romania; viodinca@yahoo.de \\ * Correspondence: patrizia.gazzola@uninsubria.it; Tel.: +39-0332-395529
}

Received: 31 July 2017; Accepted: 1 September 2017; Published: 6 September 2017

\begin{abstract}
By gliding sustainability into the mainstream areas of marketing strategy, the purpose of the current research is to analyze the influence of the entrepreneurs' orientation towards sustainability on relational marketing practices-i.e., interaction versus network marketing. Placed within a comparative setup, the investigation included a sample of 104 business owners of Romanian small and medium-sized enterprises (SMEs) from the services sector, the selection of participants being subject to well-defined pre-established criteria. Acknowledging the research gap which addresses the type of business strategy fit for entrepreneurs' orientation towards sustainability, the conceptual model integrated a categorical moderator variable (Planned/Emergent Business Strategies) as indicative of the potential heterogeneity among the hypothesized relationships. Both measurement and structural models were appraised by means of a structural equation modeling technique, respectively, component-based partial least squares (PLS-SEM). As the findings concluded, the entrepreneurs' orientation towards sustainability accounts for almost $35 \%$ of variance in interaction marketing practices and $16 \%$ of variance in network marketing practices, thus positing a higher influence on the former. Moreover, evidence was provided that the reification of the entrepreneurs' orientation towards sustainability in relational marketing practices was not significantly dependent on the type of business strategy.
\end{abstract}

Keywords: entrepreneurs' orientation towards sustainability; interaction marketing; network marketing; planned and emergent business strategies

\section{Introduction}

Sustainability is changing the way life is framed and experienced in the 21st century. It integrates concepts and theoretical models barely anticipated and discussed in the previous century, which, nowadays, have known an exponential dynamics [1-3]. The society cannot speak any more about cementing the economic grounds if the environment is deteriorating or the community is falling back $[4,5]$. Therefore, a multidimensional framework is needed to capture today's interdependent phenomena and to examine it within an up-to-date setup.

Hereby, sustainability sets itself up as a multi-concept in that it displays a framework that appraises joint-connection, reaction, and holistic reasoning, a long-term acumen which implies upgrading an overarching business model and strategies [6]. It lays emphasis on the purpose of entrepreneurial activities as a tool for sustaining a broad range of ecosystems, simultaneously 
transmitting an economic and non-economic perspective to investors, entrepreneurs, and communities, stakeholders as a whole $[7,8]$.

The emerging stream of scientific undertakings on sustainability issues steadily turns incipient preoccupations into built-in realities. Entrepreneurship and the orientation towards sustainability have glided from a debated academic topic-fit to mainstream business and entrepreneurship research interests [9,10]—-towards a substantive entrepreneurial vision [11,12]. According to Brubacker-editor of Forbes Magazine - the entrepreneurs have the power not only to unlock difficult business situations, but also to devise an innovative business pattern with new viewpoints on entrepreneurship, one that is based on an image of sustainability at the essence, and attains a conglomerate of clients along the way, demonstrating that a "sustainable business model" is not a nonproductive one [13]. Entrepreneurship is perceived as the action of "discovering" an opportunity that is available and likely to produce profit by rearranging processes to better fulfil the queries of the consumers, and implicitly, of stakeholders [14].

More recently, after systemizing a substantive body of knowledge as guest editors of a special issue of the Organization and Environment journal-i.e., Business Models for Sustainability: Origins, Present Research, and Future Avenues-Schaltegger, Hansen, and Lüdeke-Freund contended that all sustainable outcomes are dependent on generating value to a wide array of stakeholders, kept close via interpersonal and inter-firm marketing strategies- "A business is carried by a stakeholder network and-in spite of the fact that a business model is a market-oriented approach—particularly a business that contributes to sustainable development needs to create value to the whole range of stakeholders" [1] (p. 6).

So far, the extant literature has come forward with several studies that advocated these types of interconnections. For example, a recent empirical survey conducted by Cheben et al. examined the relationship between sustainability and marketing strategies within the landscape of companies from Slovakia and showed that the business model impacts the general outlook of sustainability, the emphasis being laid on the organization's endeavor to create a marketing strategy and to implement it into corporate strategy [15]. Additionally, Hapenciuc et al. conclude that-in the case of Romanian start-ups employing contemporary marketing practices (CMP) — there is a consistent preoccupation for sustainable entrepreneurship especially for the organizations applying interactive and network marketing practices [5]. Going further, Kurowska-Pysz demonstrated that there are opportunities for sustainable development in the context of cross-border (Polish-Czech) entrepreneurship, as well, but it is still relevant to investigate the catalysts of sustainability in various types of partnerships between entrepreneurs [16]. Székely and Knirsch stress the importance of responsible leadership and the roles that leaders have when adopting a sustainable position, making reference to the dialogue and partnerships that organizations need to develop with different stakeholders $[17,18]$. Keeping a balance between the marketplace, environment, and the community is, thus, a challenge that has become more demanding to sustain, and the entrepreneurs are the ones responsible-as vision and solution providers-to readjust the frame of business organizations and markets in a dynamic context.

Nevertheless, Crittenden et al. acknowledge that although the scope of sustainability is broad, many studies fail in highlighting the relationship between sustainability and the proactive management of business processes, between sustainability and marketing practices, stating that "there is little in mainstream marketing management theory, research, and practice that equips companies to deal with the 21st century operating environment in which sustainability is the consumption norm and not the exception" [2] (p. 72). The authors further add that "without a clear recognition of the fundamental constructs of sustainability, the concept will remain a fringe or voluntary activity, not a critical component of an organization's core marketing strategy", whereas Yadav urges that only by consideration and integration of the conceptual foundations from various areas can researchers support theory development in marketing [3]. A similar viewpoint was formulated by Basu and Palazzo who argued that researchers have fallen short to investigate the underlying drivers of the activities related to, or generated by, sustainability [19]. 
Corroborating, despite the growing consensus that a firm which integrates sustainability into its marketing strategy is likely to have a differential leverage over its competitors [20,21], few empirical studies have examined these issues in a comparative framework, settling the marketing typology as a pivotal criterion. As a response to this research gap and to the need to further develop the study of sustainability in relation to marketing practices, the purpose of this paper is to analyze sustainability within a tridimensional framework, considering the entrepreneurs' sustainability orientation and the nature of marketing practices as interconnected factors in Romanian young businesses. Subsequently, the research objectives are: (1) to place the inferred relationships in a comparative setup, with a view to properly map the distinctive influences of the entrepreneurs' orientation towards sustainability on relational marketing models specificity. Here, exploring distinct and multifaceted marketing practices-i.e., interaction marketing (IM) and network marketing (NM) — to give voice to business sustainability involves a more prolific perspective on the heterogeneity of the market opportunities and the entrepreneur's versatility [22]; (2) to deepen the analysis of the hypothesized relationships by including a categorical variable as moderator-the entrepreneurs' option for planned versus emergent business strategies in managing their firms-building here on the logic of previous studies [23,24]. The main questions to be answered to are: To what extent can sustainability orientation be traceable in firms' relational marketing practices? and Are entrepreneurs' sustainability orientations operationalized via relational marketing practices regardless the employed business strategy type?

Starting from these considerations, the paper was structured as follows. First, the conceptual developments are thoroughly highlighted, starting with the theoretical directions in the study of sustainability and entrepreneurs' orientation towards sustainability, continuing with the marketing models based on interaction and networks and finishing with the relationships between entrepreneurs' orientation towards sustainability and interaction, respectively, network marketing practices and the business strategy type. Subsequently, the research hypotheses and conceptual model are developed. Second, the material and methods employed in the study are depicted. Third, the measurement and structural models were assessed and the research findings are presented and discussed.

\section{Theoretical Background and Hypotheses Development}

As previously described, lining up an organization's marketing strategy with its sustainability and responsible business patterns is at the forefront of the current specialized literature [1-4]. For most communities, the market economy is the key mechanism for translating scarce resources into welfare/wellbeing and, therefore, a 'sustainability economy' is needed for tenable development. In the context of modern market-based economies, marketing is at the centre of driving and solving the problem of maximizing wellbeing via appropriate means, shaping the amount and type of resources organizations exploit, for what end and for whom. Additionally, as Hurth implies, it models what society demands by symbolically connecting offerings with fundamental human needs and with the sense of who we are and who we should be [25].

Defined by Coviello and Brodie [26] and improved by other authors throughout the years $[27,28]$ - the contemporary marketing practices (CMP) map the way companies link to their markets while considering both acknowledged and more up-to-date perspectives of marketing. Its complex and multi-angled view induces an extensive range of marketing practices likely to be used together within entrepreneurial companies as a result of environmental favourable factors. Accomplishing good performance and sustainability in the organization catalyses business adaptability and proper valuing of the market opportunities [29].

In this context, two major relational marketing strategies and practices emerge as the most sustainability-oriented, that is interaction marketing (IM) and network marketing (NM) [5] On the one hand, IM involves face-to-face interaction between individuals and is considered to be "connected" with the clients, since both participants in the relationship spend resources in order to expand reciprocally advantageous and interpersonal partnerships [27,28]. Little, Brooks, and Palmer advance that marketing is driven by customized social relationships objectivized via interpersonal interaction 
which unfold in both formal and informal ways [30]. Consequently, IM is not so much the responsibility of a specialist marketer per se, but a collective practice involving different individuals across positions and levels in the organization $[26,28]$.

On the other hand, NM is "connected" with the clients, but takes place within, and across, organizations. Here, business owners assign resources for the development of the company's position in a network-pattern of different business-level relationships [5,26,31,32]. NM activities are anchored in an inter-organizational perspective, where organizations share knowledge with a view to reinforcing their status in a network of relationships. By means of multilevel transactions occurring steadily, the organizational actors embrace an inter-firm approach and practice. Lindgreen et al. [31] suggest that relationships can range from close (interpersonal) to distant (impersonal), and have varying levels of dependence and degrees of communication. Coordination of parties through network marketing may be conducted by general managers or by "part-time" marketers from all areas in the company [28,31].

In this light, several studies [2,32-34] have addressed different sustainability drivers objectivized in the entrepreneurs' propensity towards employing relational marketing strategies (such as IM and NM). Among others, the literature discusses satisfactory interactive relationships associated with relative low retention costs, high emotion involved in interpersonal and inter-firm exchanges, long-term trust and commitment and an induced sense of closeness, all of them triggering a tenable competitive advantage [33] (p. 109). The entrepreneurs' sustainability orientation is often translated into "offering added value to 'loyal' customers in an attempt to sustain long-term relationships".

This perspective was also contended in prior research-for example, in 1996, Buttle deemed that building strong relationships with customers is indicative of the firms' orientation towards uniqueness and sustainability and towards creating a differential edge, hard to replicate by competitors [35] (p. 1). Similarly, Morgan explained that "a principal objective behind companies adopting relational strategies must, at least ultimately, be sustainable profitability" [34] (p. 485). This is why, nowadays, many organizations place relationships and relational practices to the core of their business strategies, being aware of "the need to constantly develop and refine RM strategies to keep 'ahead of the field"' [33] (p. 94). Additionally, as Egan urges "You get a much higher quality and more sustainable response when you interact with people in a clear and honest way because it gives them the chance to make a considered response to your marketing" [33] (p. 97). This being the case, on purpose to be translated into business strategies, the entrepreneurs' orientation towards sustainability is often objectivized via a variety of interactions and communication exchanges within and across organizations [2].

Among the relational marketing strategies, interaction marketing comes forward by means of strong interpersonal relationships, orientated towards bilateral support and engagement [27]. Through interaction marketing, sustainability messages can be weaved into a company's overall fabric, providing a constant flow of information to both draw in new stakeholders and keep existing stakeholders informed. The interactive features avail more chances for stakeholders to provide input, whether they consist of adding comments about certain practices or asking questions others might also want to know the answer to [36-38].

Acknowledging the aforementioned considerations, the current research endeavour places the entrepreneurs' orientation towards sustainability as an antecedent of the interaction marketing practices development and, thus, infers that:

Hypothesis 1 (H1). The entrepreneurs' orientation towards sustainability has a positive influence on the interaction marketing practices development within SMEs.

Building on an analogous logic concerned with the role of the sustainability orientation and its inherent practices and outcomes, Li, Okoroafo, and Gammoh point to the importance of the external practices which consist of "network cooperation with customers and supplier development" [39] (p. 31). This viewpoint is also supported by Zhu et al. who place the reification of the firms' performance 
potentials both in internal and external practices related to network collaboration [40]. Whereas, internally, organizations should focus on sustainable product development, externally, they should engage themselves in sustainable oriented supplier management consistent with their sustainability goals. It is in this particular front that Carter and Rogers address the imperative for strategic integration and achievement of "an organization's social, environmental, and economic goals in the systemic coordination of key inter-organizational business processes for improving the long-term economic performance of the individual company and its supply chains" [41] (p. 368).

The imperative to trace the influence of the entrepreneurs' sustainability orientation and the marketing practices was framed by Crittenden et al. in the 'market-oriented sustainability' construct which links sustainable approaches to the firms' competitive advantage [2] (p. 71). The implicit idea is that a special emphasis should be laid on the overall organizational systems, strategies and market approaches (i.e., stakeholders focus, long-term relationships focus, coordinated marketing, profitability, etc.) in order to support sustainable practice. The entrepreneurs who will objectivize the paramount function of the stakeholders perspective in the framework of their sustainability orientation will, thus, cement a viable market orientation based on networks of stakeholders [42]. Subsequently, sustainability strategies are designed to trigger a collaboration culture among the network members, Stubbs and Cocklin [43] advocating the sustainability-oriented business models which envision all stakeholders and a systems-level approach.

Pursuant to Palmer and Wilson [27], network marketing places the company into a connected set of inter-company relationships. In order to achieve sustainability goals, a company can use network marketing strategies to create complex social and economic benefits and value with customers among/ throughout an entire community network of relationships. This perspective has been supported by Hastings and Domegan [44] who state that, in the case of network marketing activities, entrepreneurs must communicate and creatively interact with the target audience, all the more so as "the growing consensus is that a firm's stakeholders are embedded directly or indirectly in interconnected networks of relationships" [2] (p. 79). The value for the target audience is collaboratively co-created by the individuals, themselves; groups within society and the network marketers within a cohesive relational web. It is, therefore, important firstly to identify the key relationship stakeholders with whom communication, interaction and value co-creation should be established $[45,46]$. Here, network marketing can serve as a framework to anchor sustainable processes for all the stakeholders involved and it serves as an interface to foster sustainability to the stakeholders [37,38]. There must be a collaborative communication within the network in order to co-create sets of offerings that have value to each target audience.

Given this, the investigation of the relationship between sustainability and network marketing practices is yet to be fully addressed, availing the proposition of the following hypothesis:

Hypothesis 2 (H2). The entrepreneurs' orientation towards sustainability has a positive influence on the network marketing practices development within SMEs.

By adopting a strategy-centric perspective, Kuosmanen and Kuosmanen [20] advance the idea that sustainability is currently assumed as a key success factor in the organizations' long-term business strategy while Hunt [21] contends that instilling sustainability into a firm's marketing strategy is likely to have a differential leverage over its competitors. In this front, Crittenden et al. militate in favour of a market-oriented framework that integrates the mechanisms and triggers of sustainability- "By incorporating sustainability into market orientation, the goal of strategic alignment of sustainability with marketing strategies is achieved to create a competitive advantage" [2] (p. 71). The firm's DNA (including here the sustainability orientation, among others) should be communicated to both internal and external stakeholders whose needs, expectations, concerns should be integrated in the strategic marketing planning. However, to substantively test these relationships, a body of evidence supporting the theories is required, as Beachcrott-Shaw and Ellis indicate [47]. 
The imperative to link sustainability to marketing practices under the aegis of an articulated business model based on well-defined business strategies was also advocated by Schaltegger, Hansen, and Lüdeke-Freund who contend that "A business model for sustainability helps describing, analysing, managing, and communicating (i) a company's sustainable value proposition to its customers, and all other stakeholders, (ii) how it creates and delivers this value, (iii) and how it captures economic value while maintaining or regenerating natural, social, and economic capital beyond its organizational boundaries" [1] (p. 6).

In this point, Maritz et al. [23] advance the imperative to widen the angle of sustainability strategy research to the point where the spectrum between planned to emergent strategy-making is fully considered. Further, according to Neugebauer, Figge, and Hahn [24], "in strategy research, there is a consensus that strategy making resides on a continuum from planned to emergent where most strategies are made in a mixed way" (p. 323). However, the authors posit that the specialized literature on business sustainability tends to generally acknowledge that sustainability strategies are elaborated in a planned way and to override the existence and contextual opportunity of the two modes. This fact afflicts a deeper comprehension of the entrepreneurs' business strategy mechanisms and, implicitly, of a highly-presumable successful implementation of the sustainability orientation.

Commonly, it is argued that planned business strategies can successfully help new companies become more efficient and sustainable [48]. An American study carried out in 2016 on 70 new US companies revealed that planning a new business venture ensures long term-viability and stands for a major premise for efficient day-to-day operations and, simultaneously, for the entrepreneurs' business strategies [49]. Articulating a coherent business plan is likely to support organizations in reducing their footprint and in having a positive impact on the environment. Another example on the importance of business planning for boosting the level of commitment to sustainability within the business is brought about by the case of a group of two companies in Bath, UK, specialized in graphic design. The case is indicative of how the elaboration of a business plan is able to translate the entrepreneurs' sustainability orientation into business strategies and practices, including here the creation and development of good relationships different stakeholders [50]. Similarly, other studies have acknowledged that business planning along with value mapping encourage entrepreneurs to engage in sustainable business practices and to smoothen the path towards positive sustainability outcomes for the company, and also for the society [51].

Several studies showed that one of the most notable actions helping the entrepreneurs to get more informed and choose their future marketing strategies or practices is the elaboration of a business plan. Among others, the elaboration of a business plan becomes a strategic endeavour which may catalyse the reification of the sustainability views into relationship-driven marketing strategies. As Zerwas and Von Korflesch explain, business planning helps a company founder establish how and when to focus his efforts and attention in various activities of the company (product and service development, marketing, purchasing, etc.) [52]. By doing that, business planning makes it easier to determine the best ordering of different business areas (e.g., marketing and promotion, obtaining inputs, and searching for capital), thereby minimizing the possibility that the venture will be postponed by setting out activities in an inefficient sequence.

Conversely, a study conducted by the Copenhagen Business School underlines that entrepreneurs should keep themselves up-to-date with changes and should be open to the advent of emergent strategies. For example, technological transformations constrain entrepreneurs to embrace a dynamic perspective in formulating pertinent strategies and, thus, business owners should look at ways to harness technological potential to develop sustainable strategies for existent or emerging markets while boosting their marketing skills [53]. Analogously, assuming that the demographic profiles of different stakeholders have an intricate and fast-changing nature, Sharafizad considers that keeping abreast of these issues as well as being conscious of the emergent social norms and lifestyle expectations support the topicality of their marketing strategies and practices [54]. 
Acknowledging this research problem, the current study presumes the moderating role of business strategy type in the relationship between the entrepreneurs' orientation towards sustainability and the marketing practices developed in SMEs. Credit is given to the approaches of Maritz et al. [23] and Neugebauer, Figge, and Hahn [24] who urge the need to consider the wide continuum from planned, to emergent, business strategies when discussing sustainability issues. As a consequence, we infer that:

Hypothesis 3 (H3). The entrepreneurs' orientation towards sustainability has a positive influence on the relational marketing practices development within SMEs in the context of planned business strategies-i.e., on interaction marketing (H3A) and network marketing (H3B).

Hypothesis 4 (H4). The entrepreneurs' orientation towards sustainability has a positive influence on the relational marketing practices development within SMEs in the context of emergent business strategies-i.e., on interaction marketing $(H 4 A)$ and network marketing $(H 4 B)$.

Hypothesis 5 (H5). The entrepreneurs' orientation towards sustainability has a higher positive significant influence on relational marketing practices development within SMEs in the context of planned business strategies than in the context of emergent business strategies.

Given these assumptions, we have developed a research model integrating the relationships between the entrepreneurs' orientation towards sustainability and interaction and network marketing practices development within SMEs, considering planned versus emergent business strategies as a moderator (Figure 1).

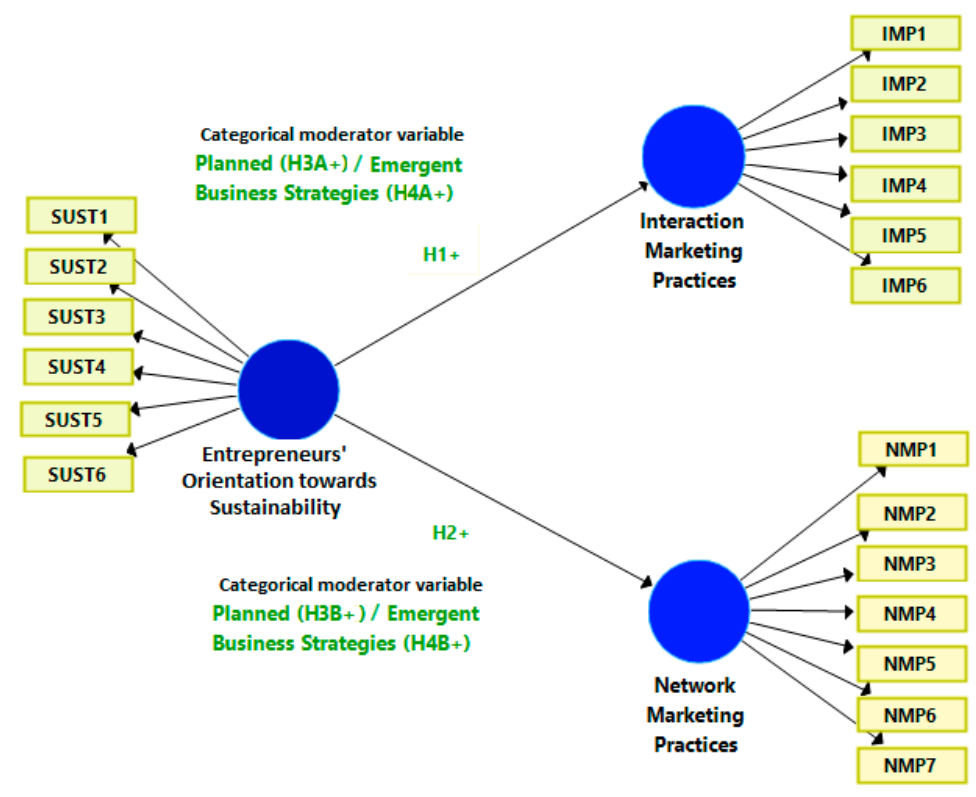

Figure 1. Research model with hypotheses.

\section{Materials and Methods}

\subsection{Data Collection and Sample}

A total of 128 Romanian small- and medium-sized enterprises (with a market experience of maximum five years) were invited to participate at a survey concerning the influence of the entrepreneurs' orientation towards sustainability and two different types of marketing practices, namely interaction and network marketing practices. The entrepreneurs' contacts were retrieved from a national project focused on the development of entrepreneurial competences among SMEs owners. A total of 104 valid questionnaires were entirely filled in, engendering a response rate of 
$81.25 \%$. The investigation was carried out between 8 and 25 February 2016. Questionnaires were sent on the subjects' e-mails upon their acceptance to take part in the survey. In the research framework, the business owners had the role of key informants of their organizations. Additionally, on purpose to ensure a pertinent level of sample homogeneity, several selection criteria were pre-established: (1) only young business were included; (2) the SMEs operated in the services sector; and (3) the number of employees ranged between 3 and 12 .

In order to limit the participants' subjectivity in approaching the raised questions, the research instrument consisted of closed-ended multi-item constructs which were measured on five-point Likert scales varying from "Never" (1) to "Always" (5) (2 = Rarely, $3=$ Sometimes, $4=$ Often).

\subsection{Measures}

The items in the questionnaire primarily addressed the entrepreneurs' approaches on sustainability issues (further referred as "Entrepreneurs' Orientation towards Sustainability") and the Interaction and Network Marketing Practices employed, as they were theoretically brought forward. The questions were grouped into four major categories, the first three describing the multi-item dimensions in the research model (as presented in Table 1) and the last one comprising business characteristics (including here the business strategy type, i.e., planned versus emergent, in line with Maritz et al. [23] and Neugebauer, Figge, and Hahn [24]. At this level, it should be mentioned that the items comprised by the second and third constructs, that is IM, respectively, NM, are part of a standardized research instrument—contemporary marketing practices (CMP)—advanced by Coviello, Milley, and Marcolin [26], and further improved by Brodie, Coviello and Winklhofer [28].

Albeit the items pertaining to each category are tributary to measurement scales tested in prior researches, a factor analysis procedure was computed aiming at the exploration of the factors deriving from the statements and then to bring forward a pertinent measure of the analysed dimensions. The accuracy of the method was verified by means of the Bartlett and Kaiser-Meyer-Olkin (KMO) test as it allows the testing of the factor analysis adequacy in the context of the collected data. The obtained value of the test (i.e., $\mathrm{KMO}=0.811$, Sig. $=0.000$ ) indicated the adequacy of using the method for the present research.

Table 1. Constructs and items.

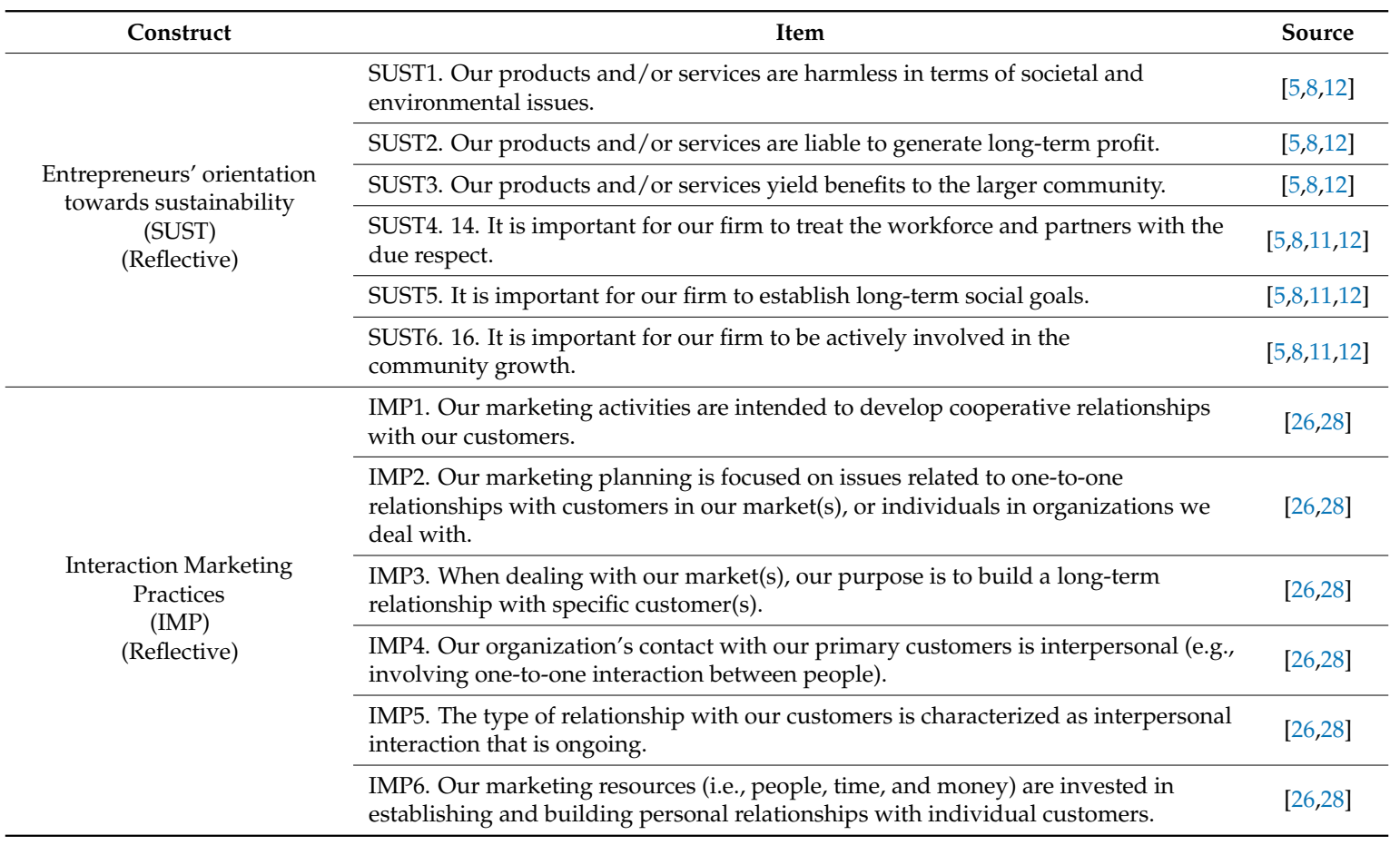


Table 1. Cont.

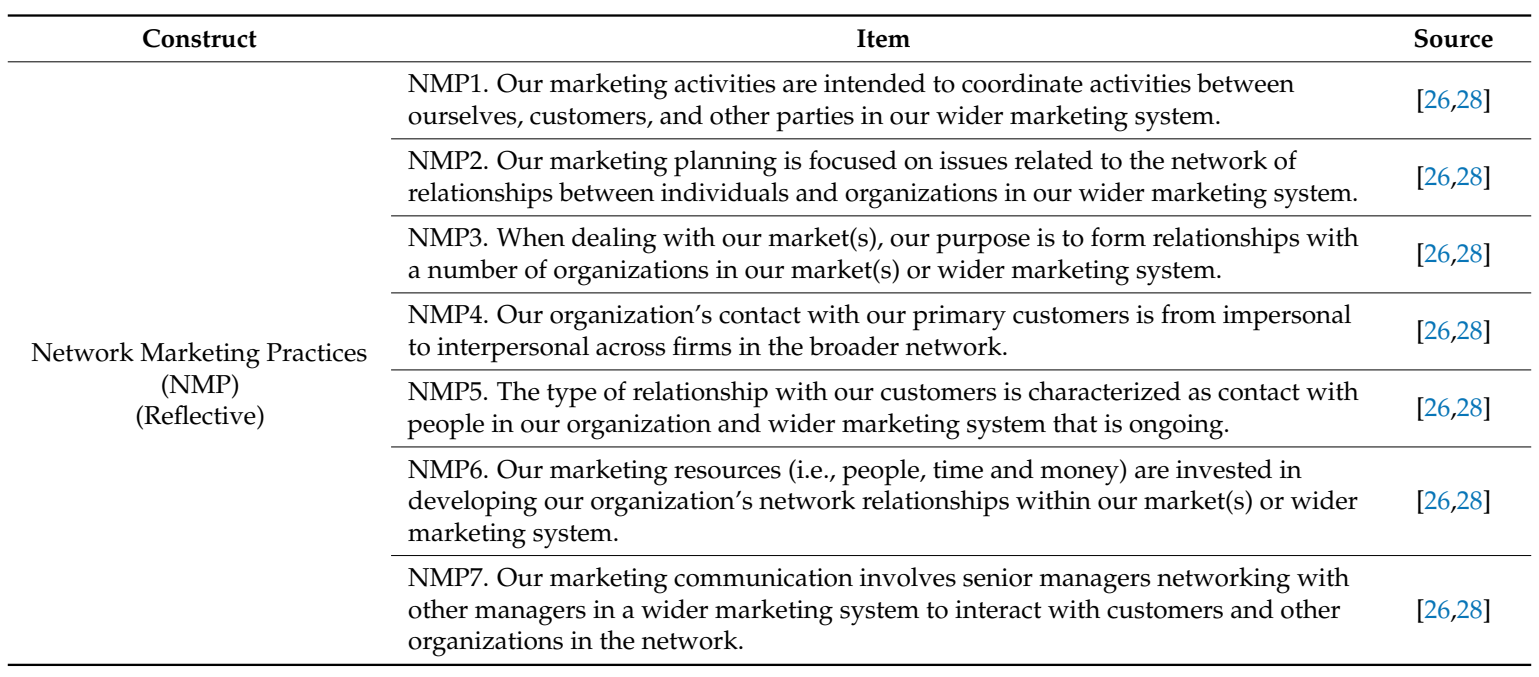

That being the case, a principal components extraction was unfolded, employing the varimax orthogonal rotation which maximizes the variance of the factor components and, thus, ensures a smaller loading of indicators on every factor. As theoretically inferred, the analysis brought to the fore three factors comprising $61.10 \%$ of the information embedded in the original set of data (Table 2). The factor structure conforms to the statistical requirements pointed out by Costello and Osborne [55] (p. 3) -it comprises more than three indicators and their loadings are over the threshold of 0.30.

Table 2. Factor analysis.

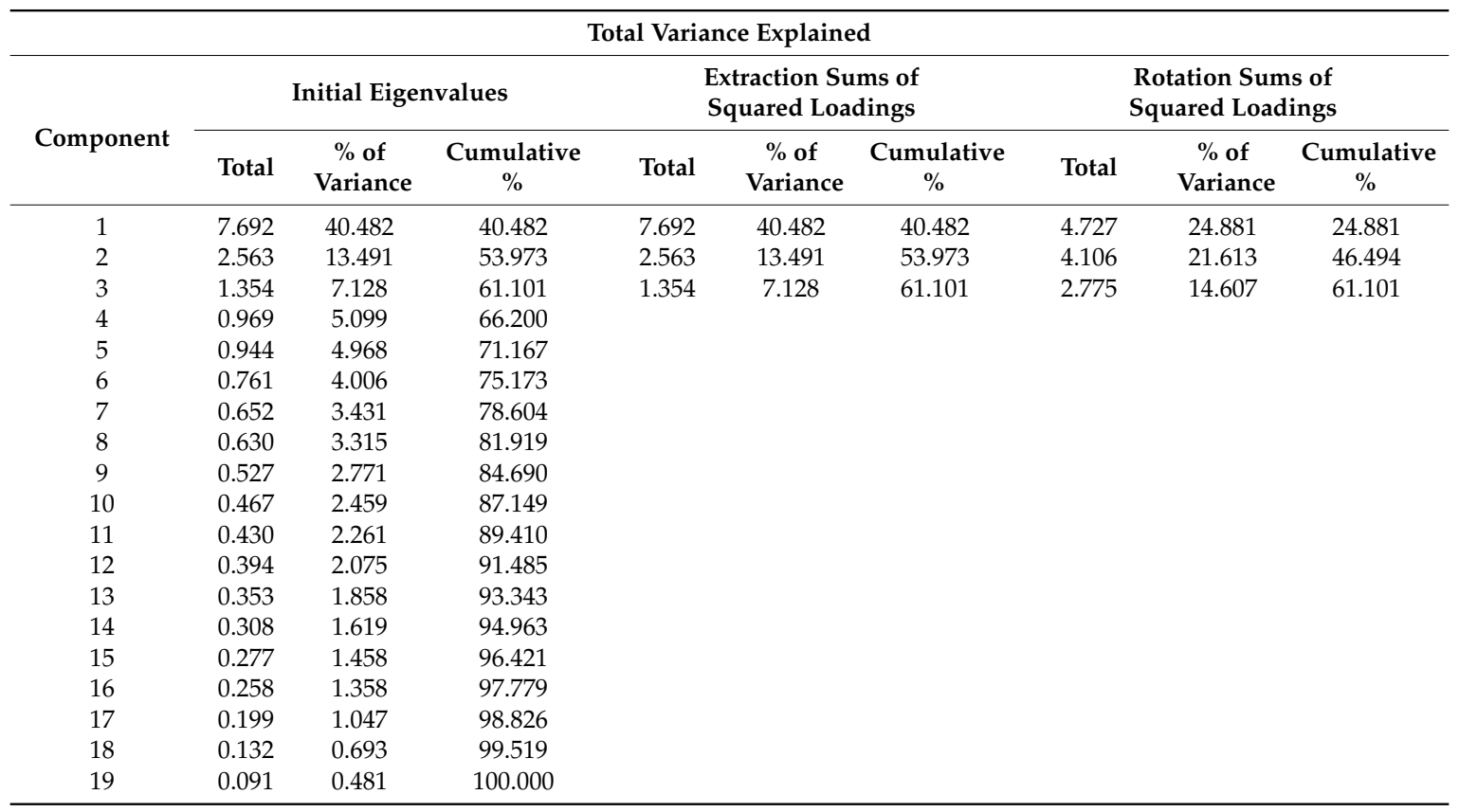

Extraction method: principal component analysis.

\subsection{Method}

The measurement and structural models were appraised via a structural equation modelling technique - component-based partial least squares (PLS-SEM)—advanced by Hair, Ringle, and Sarstedt [56], and supported by Henseler et al. [57], Henseler, Ringle, and Sinkovics [58], Chin [59]; 
Henseler, Ringle, and Sarstedt [60], etc. Given the exploratory nature of the current research endeavor, SmartPLS software version 3.0 was used [61] — "PLS-SEM (also called PLS path modelling) is primarily used to develop theories in exploratory research. It does this by focusing on explaining the variance in the dependent variables when examining the model" [62] (p. 4). PLS-SEM-assumed as a variance-based approach to SEM-estimates coefficients that increase the $R^{2}$ values of the (target) endogenous constructs and is, thus, "the preferred method when the research objective is theory development and explanation of variance (prediction of the constructs)" [62] (p. 14).

\section{Results}

\subsection{Measurement Model Assessment}

In order to assess the measurement model, the first step was to analyze the psychometric properties of the constructs. In line with Barclay, Higgins, and Thompson [63], emphasis was laid on the analysis of the convergent validity, individual item reliability, composite reliability, and discriminant validity of the measurement model.

The convergent validity was scrutinized using the factor loadings and cross-loadings of the indicators on their reflective constructs, the average variance extracted (AVE), and the composite reliability (CR) and reliability (Cronbach's alpha, rho_alpha) as points of reference (as illustrated in Tables 3 and 4).

As presented in Table 3, the reflective item factor loadings exceeded the threshold of 0.65 while the AVE values were above the 0.50 minimum value required. The composite reliability $[62,64]$ and Cronbach's alpha results of all the advanced indicators were higher than the recommended threshold of 0.7 [65]. For example, CR values ranged from 0.86 to 0.91 while AVE ranged from 0.52 to 0.61 .

Table 3. Psychometric properties of reflective constructs.

\begin{tabular}{|c|c|c|c|c|c|c|}
\hline Construct & Cronbach Alp Ha & Rho_Alpha & CR & AVE & Indicator & Loadings \\
\hline \multirow{6}{*}{$\begin{array}{l}\text { Entrepreneurs' } \\
\text { orientation } \\
\text { Towards } \\
\text { sustainability } \\
\text { (Reflective) }\end{array}$} & \multirow{6}{*}{0.874} & \multirow{6}{*}{0.881} & \multirow{6}{*}{0.904} & \multirow{6}{*}{0.612} & SUST1 & 0.743 \\
\hline & & & & & SUST2 & 0.751 \\
\hline & & & & & SUST3 & 0.840 \\
\hline & & & & & SUST4 & 0.741 \\
\hline & & & & & SUST5 & 0.794 \\
\hline & & & & & SUST6 & 0.819 \\
\hline \multirow{6}{*}{$\begin{array}{c}\text { Interaction Marketing } \\
\text { Practices } \\
\text { (IMP) } \\
\text { (Reflective) }\end{array}$} & \multirow{6}{*}{0.814} & \multirow{6}{*}{0.824} & \multirow{6}{*}{0.865} & \multirow{6}{*}{0.519} & IMP1 & 0.651 \\
\hline & & & & & IMP2 & 0.658 \\
\hline & & & & & IMP3 & 0.803 \\
\hline & & & & & IMP4 & 0.729 \\
\hline & & & & & IMP5 & 0.689 \\
\hline & & & & & IMP6 & 0.777 \\
\hline \multirow{7}{*}{$\begin{array}{c}\text { Network Marketing } \\
\text { Practices } \\
\text { (NMP) } \\
\text { (Reflective) }\end{array}$} & \multirow{7}{*}{0.885} & \multirow{7}{*}{0.901} & \multirow{7}{*}{0.910} & \multirow{7}{*}{0.593} & NMP1 & 0.723 \\
\hline & & & & & NMP2 & 0.748 \\
\hline & & & & & NMP3 & 0.837 \\
\hline & & & & & NMP4 & 0.786 \\
\hline & & & & & NMP5 & 0.754 \\
\hline & & & & & NMP6 & 0.846 \\
\hline & & & & & NMP7 & 0.681 \\
\hline
\end{tabular}


Table 4. Cross-loadings.

\begin{tabular}{cccc}
\hline Indicators & SUST & IMP & NMP \\
\hline IMP1 & 0.464 & 0.651 & 0.448 \\
IMP2 & 0.341 & 0.658 & 0.492 \\
IMP3 & 0.492 & 0.803 & 0.613 \\
IMP4 & 0.402 & 0.729 & 0.409 \\
IMP5 & 0.315 & 0.689 & 0.605 \\
IMP6 & 0.476 & 0.777 & 0.528 \\
NMP1 & 0.271 & 0.476 & 0.723 \\
NMP2 & 0.241 & 0.559 & 0.748 \\
NMP3 & 0.318 & 0.582 & 0.837 \\
NMP4 & 0.291 & 0.537 & 0.786 \\
NMP5 & 0.400 & 0.610 & 0.754 \\
NMP6 & 0.348 & 0.622 & 0.846 \\
NMP7 & 0.216 & 0.389 & 0.681 \\
SUST1 & 0.743 & 0.389 & 0.210 \\
SUST2 & 0.751 & 0.405 & 0.288 \\
SUST3 & 0.840 & 0.470 & 0.239 \\
SUST4 & 0.741 & 0.455 & 0.309 \\
SUST5 & 0.794 & 0.520 & 0.417 \\
SUST6 & 0.819 & 0.494 & 0.362 \\
\hline
\end{tabular}

Additionally, the discriminant validity of the measurement model was tested by comparing the square roots of the AVEs with other correlation scores in the correlation matrix (as indicated in Table 5). None of the construct correlations values (non-diagonal entries) were higher than corresponding square root of AVE (diagonal entries), conforming thus to Fornell and Larcker's guidelines [65].

Table 5. Discriminant validity of measurement model.

\begin{tabular}{cccc}
\hline & SUST & IMP & NMP \\
\hline SUST & 0.782 & & \\
IMP & 0.589 & 0.720 & \\
NMP & 0.400 & 0.712 & 0.770
\end{tabular}

Diagonals represent the square root of the average variance extracted while the off-diagonals are correlations among constructs.

A check of the extent of multicollinearity among constructs was also performed, by employing the variance inflation factor (VIF), pursuant to Diamantopoulos and Siguaw's [66] indications. The obtained results highlighted that multicollinearity is not an issue with the data, given the fact that VIF scores ranged from 1.41 to 3.06 (thus, below the threshold value of 3.3). At the same time, the issue of common method bias was investigated following the recommendations of Harman [67] - the one-factor test was applied, via the unrotated principal component factor analysis. The findings confirmed that none of the factors accounted for more than $50 \%$ of variance.

\subsection{Structural Model Assessment}

In order to assess the structural model and to test the advanced hypotheses, the $R^{2}$, beta and $t$-values were computed [68], by applying a bootstrapping procedure with 5000 resamples (as indicated in Table 6). 
Table 6. Results of the structural model analysis (hypotheses testing).

\begin{tabular}{ccccccc}
\hline Hypothesis & Relationship & Std. Beta & Std. Dev. & $\boldsymbol{t}$-Value & Decision & $\boldsymbol{R}^{\mathbf{2}}$ \\
\hline H1 & SUST -> IMP & 0.589 & 0.095 & $6.213^{* *}$ & Supported & 0.347 \\
H2 & SUST -> NMP & 0.400 & 0.101 & $3.942^{* *}$ & Supported & 0.160 \\
\hline \multicolumn{7}{c}{${ }^{* *} p<0.001}$.
\end{tabular}

The results indicated that the endogenous constructs (i.e., IM, respectively NM) are significantly influenced and determined by the exogenous construct, namely the Entrepreneurs' Orientation towards Sustainability. In the framework of the investigated Romanian SMEs whose owners participated in the survey, the entrepreneurs' orientation towards sustainability accounts for almost $35 \%$ of variance in Interaction Marketing Practices and 16\% of variance in Network Marketing Practices.

The relationship between Entrepreneurs' Orientation towards Sustainability and the Interaction Marketing Practices is positive and significant $(\beta=0.589, p<0.001)$, thus, supporting the first hypothesis of the study, that is, H1: The entrepreneurs' orientation towards sustainability has a positive influence on the interaction marketing practices development within SMEs. On this front, the Romanian business owners' marketing practices are liable to be analysed and appraised through the lens of their approaches (attitudes and behaviours) towards people, profit and planet, as pillars of sustainability.

Focusing on the relationship between the Entrepreneurs' Orientation towards Sustainability and the Network Marketing Practices, the former has a positive and significant influence on the latter $(\beta=0.400, p<0.001)$, hence, supporting the second hypothesis of the study, namely $H 2$ : The entrepreneurs' orientation towards sustainability has a positive influence on the network marketing practices development within SMEs. The pattern is quite similar to the one of the first hypothesis in that the network marketing practices are tributary to a great extent to the entrepreneurs' approaches towards business sustainability grounds.

Placing the discussion in a comparative framework-Interaction versus Network Marketing Practices-the findings have supported a higher influence of the Entrepreneurs' Orientation towards Sustainability on the interaction model to the detriment of the network model, as revealed by the coefficients of determination $\left(R_{I M P}^{2}=0.347\right.$ versus $\left.R^{2}{ }_{N M P}=0.160\right)$, and indicated by the coefficient paths $(\beta=0.589$ versus $\beta=0.400$ ).

Acknowledging the possibility that the participants at the study may be heterogeneous in their approaches and that heterogeneous data structures may also apply to the current research, engendering significant differences in path coefficients across two or more groups of respondents, a parametric partial least squares multi-group analysis (PLS-MGA) was performed in line with Sarstedt et al. [69] and Hair et al. [62] - "PLS-MGA refers to a set of different techniques that have been developed for comparing PLS model estimates across groups of data" [62] (p. 247). Consequently, separate bootstrap analyses were conducted on $\mathrm{g} 0$ and $\mathrm{g} 1$ sub-samples, assuming that the categorical moderator variable "Planned/Emergent Business Strategies" influences the relationships in the PLS path model. From a technical standpoint, the subjects' assertions on whether they resorted, or not, to strategic business planning - used as a categorical moderator variable - split the data set into two entrepreneurial groups: the entrepreneurs who have elaborated their marketing strategies and practices based on overall planned business strategies in accordance with their sustainability orientation and the entrepreneurs who have considered the benefits of emergent business strategies as suitable for their sustainability orientation (the results are displayed in Table 7).

As shown in Table 7, the bootstrapping results support the positive significant influences of the entrepreneurs' orientation towards sustainability on the interaction and network marketing practices in the case of both business owners who employ planned business strategies (SUST $\rightarrow$ IMP: $\beta=0.662$, $p<0.001$; SUST $->$ NMP: $\beta=0.491, p=0.001$ ), thus confirming H3A and H3B, and who employ emergent business strategies (SUST $->$ IMP: $\beta=0.593, p<0.001$; SUST $\rightarrow$ NMP: $\beta=0.383, p=0.01$ ), thus confirming H4A and H4B. 
Table 7. Bootstrapping results for PLS-MGA (hypotheses testing).

\begin{tabular}{cccccc}
\hline Hypothesis & Relationship & Std. Beta & Std. Dev. & $t$-Value & Decision \\
\hline H3A & $\begin{array}{c}\text { SUST - > IMP } \\
\text { (Planned Business Strategies) }\end{array}$ & 0.662 & 0.159 & $4.168^{* *}$ & Supported \\
\hline H4A & $\begin{array}{c}\text { SUST -> NMP } \\
\text { (Planned Business Strategies) }\end{array}$ & 0.491 & 0.146 & $3.364^{* *}$ & Supported \\
\hline H3B & $\begin{array}{c}\text { SUST - > IMP } \\
\text { (Emergent Business Strategies) }\end{array}$ & 0.593 & 0.108 & $5.471^{* *}$ & Supported \\
\hline H4B & $\begin{array}{c}\text { SUST -> NMP } \\
\text { (Emergent Business Strategies) }\end{array}$ & 0.383 & 0.146 & $2.630^{*}$ & Supported \\
\hline
\end{tabular}

Although the PLS-MGA indicated the existence of differences in path coefficients between the two groups of respondents, the results were not significant $(p>0.05)$, as illustrated in Table 8 .

Table 8. PLS-MGA (H5 testing).

\begin{tabular}{ccc}
\hline Relationship & Path Coefficients-Diff (g1-g0) & $\boldsymbol{p}$-Value (g1 vs. g0) \\
\hline SUST -> IMP & 0.069 & 0.300 \\
SUST -> NMP & 0.107 & 0.234 \\
\hline
\end{tabular}

In the case of the present research sample, there are no significant differences between the inferred relationships using the type of business strategy as a categorical moderator variable. As a consequence, H5 (The entrepreneurs' orientation towards sustainability has a higher positive significant influence on relational marketing practices development within SMEs in the context of planned business strategies than in the context of emergent business strategies) was not supported.

\section{Discussion}

\subsection{Research Contribution and Originality: Theoretical and Practical Implications}

By corroborating the aforementioned results, it can be concluded that the entrepreneurs' orientation towards business sustainability has significant and positive influences on both interaction and network marketing practices. The meaningfulness of the relationships was confirmed irrespective of the business strategy type, respectively, planned/emergent business strategies. Although the coefficient paths were higher in the case of the sub-sample of entrepreneurs who employed planned strategies (relying on articulated business plans), the findings showed that the differences between sub-samples are purely aleatory, thus, statistically non-significant at the population level.

In this vein, the evidence support the strong connection between business sustainability and the Interaction Marketing approach, that is, developing customized formal or informal relationships between individuals, investing resources to underpin mutually beneficial and interpersonal dyads, in an active and adaptive manner. The entrepreneurs' orientation towards sustainability can be also mapped within the interaction marketing practices through the multilevel marketing approach as IMP may involve a number of individuals concentrated on: developing one-to-one cooperative relationships with the customers, building a long-term relationship with specific customer(s), strengthening ongoing interpersonal interaction via a proper allocation of marketing resources [26,28]. The findings are consistent with previous studies $[5,8,12]$ supporting the relationships between sustainability and marketing practices.

Giving credit to the evidence provided by Maritz et al. [23] and Neugebauer, Figge, and Hahn [24], according to whom business sustainability can be achieved both via planned and emergent strategies, the results underscored the statistical significance of the inferred relationship between entrepreneurs' orientation towards sustainability and interaction marketing practices in both cases. 
Focusing on the connections between business sustainability and the network marketing approach, the findings confirmed the existence of a significant and positive relationship between the two dimensions. In line with the obtained results, the entrepreneurs' orientation towards sustainability can be mapped-from a marketing perspective-in their commitment to develop an interlinked firm-level web of relationships. This is accomplished through business and social transactions over time, as a result of developing and maintaining individual, interaction-based relationships. In fact, network marketing makes a step forward towards cementing relationships both at the individual and firm levels. Relationships become, progressively, part of a larger web, objectivizing a wide array of dependence and communication degrees. The results are indicative of previous studies $[5,8,28,31]$ which concluded the presence of strong ties between the predilection for sustainability and the network marketing approach.

Furthermore, as in the case of interaction marketing, the results underscored the significance of the inferred relationship between entrepreneurs' orientation towards sustainability and network marketing practices no matter the business strategy type employed by the questioned entrepreneurs-be it planned or emergent. These findings are also consistent with the proposition of Maritz et al. [23] and Neugebauer, Figge, and Hahn [24]. Conversely, the evidence challenges the studies positing that planned business strategies are the only ones consistent with a sustainability orientation [48-52] or that emergent business strategies are more suitable in today's versatile business environment.

By placing the inferred relationships between sustainability and the interaction marketing practices, respectively, network marketing practices in a comparative framework, the current investigation brings to the fore a novel perspective on the distinctive influences of the entrepreneurs' orientation towards sustainability on marketing relational models specificity. Furthermore, it contributes to the existing literature in a multidimensional manner.

First of all, it tackles sustainability and the entrepreneurs' sustainability orientations in the frame of reference of young businesses (SMEs developing activities for around five years). Secondly, via the examination of Romanian young companies, the research is descriptive of the interplay between sustainability and relational marketing practices in an emerging economy, hereby providing a phenomenological view on how the extant theoretical developments are reified in practice. Thirdly, the study lays emphasis on the relational perspective as defined by Coviello and Brodie [26], comprising interaction marketing and network marketing as landmarks of the most sustainability-driven, interpersonal and inter-organizational marketing practices. Fourthly, the research focus shifts from understanding sustainability through the lens of corporate social responsibility practices to "a core component of marketing strategy", as Crittenden et al. [2] (p. 82) affirm. Lastly, the hypothesized relationships are discussed in the twofold framework of planned versus emergent business strategies, considering the business strategy type as derived from a well-defined business model $[1,6,15,43]$.

From a methodological perspective, the usage of a parametric partial least squares multi-group analysis (PLS-MGA) enabled a more intricate examination of the desired phenomena, demonstrating that the sub-samples heterogeneity in not an issue in the context of the present research. Therefore, the assumption that the overall conceptual model may be misleading was statistically rejected and novel insights for researchers in their modeling undertakings were provided.

Furthermore, in spite of the fact that "the PLS-SEM results are to some extent static in that they usually build on cross-sectional data" [70] (p. 4604), the study made a step forward to the "wealth of knowledge that still needs to be acquired and accumulated with respect to market-oriented sustainability" [2] (p. 82).

From a practical point of view, the findings have two-fold implications. On the one hand, they support the fact that the entrepreneurial orientation towards sustainability stands for a compelling antecedent of relational marketing practices, that is, of specific interpersonal and inter-organizational relationships which consolidate tenable collaborations and competitive advantages for all the stakeholders involved, as also confirmed by previous studies [1,2,8,29]. With a view to harness engagement from the stakeholders, the entrepreneurs should integrate mutual sustainability concerns 
in their business models and operationalize them through customized market-oriented strategies. On the other hand, the findings are descriptive of the business landscape from an emerging European country where entrepreneurs' sustainability orientation is still in an embryonic phase. Against this backdrop, the evidence brought about by the current study may be considered a pertinent signal that the entrepreneurs of young businesses have stepped forward towards a sustainability-driven orientation, objectivized in consistent marketing practices.

\subsection{Limitations and Future Research Directions}

As any other exploratory study, the present research is open to further developments.

In this respect, the conceptual model may be extended and improved by integrating other constructs (i.e., Database Marketing or E-marketing) and by testing the influences of the entrepreneurs' orientation towards sustainability on each marketing typology. Likewise, the conceptual model would benefit from the inclusion of factors or moderators accounting for the entrepreneurs' choice for particular marketing strategies and practices (i.e., industry type, business competitiveness, organizational culture, dynamic capabilities, etc.).

Additionally, the investigation of the inferred relationships on cross-national samples would enlarge and refine the analytical landscape, allowing multiple-context comparisons. For example, the replication of the survey in the case of similar samples from other countries in Europe would offer fresh evidence in this front.

Acknowledgments: No grants were used for the research and publication of the article. Only personal funds were employed.

Author Contributions: Patrizia Gazzola and Violeta Mihaela Dincă reviewed and revised the literature on the topic. Elena-Mădălina Vătămănescu designed the questionnaire items, developed and revised the methodological and empirical sections, and analyzed the data. Patrizia Gazzola and Roberta Pezzetti discussed and revised the implications and limitations of the results.

Conflicts of Interest: The authors declare no conflict of interest.

\section{References}

1. Schaltegger, S.; Hansen, E.G.; Lüdeke-Freund, F. Business Models for Sustainability: Origins, Present Research, and Future Avenues. Organ. Environ. 2016, 29, 3-10. [CrossRef]

2. Crittenden, W.L.; Crittenden, W.F.; Ferrell, L.K.; Ferrell, O.C.; Pinney, C.C. Market-oriented sustainability: A conceptual framework and propositions. J. Acad. Mark. Sci. 2011, 39, 71-85. [CrossRef]

3. Yadav, M.S. The decline of conceptual articles and implications for knowledge development. J. Mark. 2010, 74, 1-19. [CrossRef]

4. Arnold, M. Fostering sustainability by linking co-creation and relationship management concepts. J. Clean. Prod. 2017, 140, 179-188. [CrossRef]

5. Hapenciuc, C.V.; Pînzaru, F.; Vatamanescu, E.-M.; Stanciu, P. Converging Sustainable Entrepreneurship and the Contemporary Marketing Practices. An Insight into Romanian Start-Ups. Amfiteatru Econ. 2015, 17, 938-954.

6. Zucchella, A.; Urban, S. Futures of the sustainable firm: An evolutionary perspective. Futures 2014, 63, 86-100. [CrossRef]

7. Shepherd, D.; Patzelt, H. The new field of sustainable entrepreneurship: Studying entrepreneurial action linking "what is to be sustained" with "what is to be developed". Entrep. Theory Pract. 2011, 35, 137-166. [CrossRef]

8. Vătămănescu, E.-M.; Pînzaru, F.; Andrei, A.G.; Zbuchea, A. Investigating SMES Sustainability with Partial Least Squares Structural Equation Modelling. Transform. Bus. Econ. 2016, 15, 259-273.

9. Cohen, B.; Winn, M.I. Market imperfection, opportunity and sustainable entrepreneurship. J. Bus. Ventur. 2007, 22, 29-49. [CrossRef]

10. Dean, T.J.; McMullen, J.S. Toward a theory of sustainable entrepreneurship: Reducing environmental degradation through entrepreneurial action. J. Bus. Ventur. 2007, 22, 50-76. [CrossRef] 
11. Kuckertz, A.; Wagner, M. The influence of sustainability orientation on entrepreneurial intentionsInvestigating the role of business experience. J. Bus. Ventur. 2010, 25, 524-539. Available online: http:/ / dx.doi.org/10.1016/j.jbusvent.2009.09.001 (accessed on 11 July 2017). [CrossRef]

12. Soto-Acosta, P.; Cismaru, D.-M.; Vătămănescu, E.-M.; Ciochină, R.S. Sustainable Entrepreneurship in SMEs: A Business Performance Perspective. Sustainability 2016, 8, 342. [CrossRef]

13. Brubacker, R. The Next Best Thing for Entrepreneurs: Sustainability. Available online: https://www.forbes. com/sites/ceibs/2015/09/09/the-next-big-thing-for-entrepreneurs-sustainability/\#795309f85aa9 (accessed on 12 July 2017).

14. Pădurean, M.A.; Nica, A.M.; Nistoreanu, P. Entrepreneurship in tourism and financing through the Regional Operational Programme. Amfiteatru Econ. 2015, 17, 183-197.

15. Chebeň, J.; Lančarič, D.; Savov, R.; Tóth, M.; Tlučhoř, J. Towards Sustainable Marketing: Strategy in Slovak Companies. Amfiteatru Econ. 2015, 17, 855-871.

16. Kurowska-Pysz, J. Opportunities for cross-border entrepreneurship development in a cluster model exemplified by the Polish-Czech region. Sustainability 2016, 8, 230. [CrossRef]

17. Székely, F.; Knirsch, M. Responsible leadership and corporate social responsibility: Metrics for sustainable performance. Eur. Manag. J. 2005, 23, 628-647. [CrossRef]

18. Hörisch, J. The role of sustainable entrepreneurship in sustainability transitions: A conceptual synthesis against the background of the multi-level perspective. Adm. Sci. 2015, 5, 286-300. [CrossRef]

19. Basu, K.; Palazzo, G. Corporate social responsibility: A process model of sense-making. Acad. Manag. Rev. 2008, 33, 122-136. [CrossRef]

20. Kuosmanen, T.; Kuosmanen, N. How not to measure sustainable value (and how one might). Ecol. Econ. 2009, 69, 235-243. [CrossRef]

21. Hunt, S.D. The evolution of resource-advantage theory: Six events, six realizations, six contributions. J. Hist. Res. Mark. 2012, 4, 7-29.

22. Font, X.; McCabe, S. Sustainability and marketing in tourism: Its contexts, paradoxes, approaches, challenges and potential. J. Sustain. Tour. 2017, 25, 869-883. [CrossRef]

23. Maritz, R.; Pretorius, M.; Plant, K. Exploring the Interface between Strategy-Making and Responsible Leadership. J. Bus. Eth. 2011, 98, 101-113. [CrossRef]

24. Neugebauer, F.; Figge, F.; Hahn, T. Planned or Emergent Strategy Making? Exploring the Formation of Corporate Sustainability Strategies. Bus. Strategy Environ. 2016, 25, 323-336. [CrossRef]

25. Hurth, V.; Peck, J.; Jackman, D.; Wensing, E. Reforming Marketing for Sustainability: Towards a Framework for Evolved Marketing; Working Paper; Plymouth University: Plymouth, UK, 2015.

26. Coviello, N.; Brodie, R. Contemporary marketing practices of consumer and business-to-business firms: How different are they? J. Bus. Ind. Mark. 2001, 16, 382-400. [CrossRef]

27. Palmer, R.; Wilson, H. An Exploratory Case Study Analysis of Contemporary Marketing Practices. J. Strateg. Mark. 2009, 17, 169-187. [CrossRef]

28. Brodie, R.; Coviello, N.; Winklhofer, H. Contemporary marketing practices research program: A review of the first decade. J. Bus. Ind. Mark. 2008, 23, 84-94. [CrossRef]

29. Choongo, P.; Van Burg, E.; Paas, L.J.; Masurel, E. Factors influencing the identification of sustainable opportunities by SMEs: Empirical evidence from Zambia. Sustainability 2016, 8, 81. [CrossRef]

30. Little, V.; Brookes, R.; Palmer, R. Research informed teaching and teaching-informed research: The CMP living case study approach to understanding marketing practice. J. Bus. Ind. Mark. 2008, 23, 124-134. [CrossRef]

31. Lindgreen, A.; Davis, R.; Brodie, R.J.; Buchanan-Oliver, M. Pluralism in contemporary marketing practices. Int. J. Bank Mark. 2000, 18, 294-308. [CrossRef]

32. Păduraru, T.; Vătămănescu, E.-M.; Andrei, A.G.; Pînzaru, F.; Zbuchea, A.; Maha, L.G.; Boldureanu, G. Sustainability in Relationship Marketing: An Exploratory Model for the Industrial Field. Environ. Eng. Manag. J. 2016, 15, 1635-1647.

33. Egan, J. Relationship marketing. In Exploring Relational Strategies in Marketing, 4th ed.; Pearson Education Limited: London, UK, 2011.

34. Morgan, R.M. Relationship marketing and marketing strategy. In Handbook of Relationship Marketing; Sheth, J.N., Parvakiyar, A., Eds.; Sage: Thousand Oaks, CA, USA, 2000; pp. 481-504.

35. Buttle, F.B. Relationship Marketing Theory and Practice; Paul Chapman: London, UK, 1996. 
36. Andrei, A.G.; Zait, A.; Vătămănescu, E.M.; Pînzaru, F. Word-of-mouth generation and brand communication strategy: Findings from an experimental study explored with PLS-SEM. Ind. Manag. Data Syst. 2017, 117, 478-495. Available online: https:// doi.org/10.1108/IMDS-11-2015-0487 (accessed on 11 July 2017). [CrossRef]

37. Andrei, A.G.; Gazzola, P.; Zbuchea, A.; Alexandru, V.A. Modeling socially responsible consumption and the need for uniqueness: A PLS-SEM approach. Kybernetes 2017, 4, in press. Available online: https: / / doi.org/10.1108/K-03-2017-0103 (accessed on 25 July 2017). [CrossRef]

38. Vătămănescu, E.M.; Nistoreanu, B.G.; Mitan, A. Competition and Consumer Behavior in the Context of the Digital Economy. Amfiteatru Econ. 2017, 19, 354-366.

39. Li, S.; Okoroafo, S.; Gammoh, B. The Role of Sustainability Orientation in Outsourcing: Antecedents, Practices, and Outcomes. J. Manag. Sustain. 2014, 4, 27-36. [CrossRef]

40. Zhu, Q.; Sarkis, J.; Lai, K.H. Examining the effects of green supply chain management practices and their mediations on performance improvements. Int. J. Prod. Res. 2012, 50, 1377-1394. [CrossRef]

41. Carter, C.R.; Rogers, D.S. A framework of sustainable supply chain management: Moving toward new theory. Int. J. Phys. Distrib. Logist. Manag. 2008, 38, 360-387. [CrossRef]

42. Maignan, I.; Ferrell, O.C. Corporate social responsibility and marketing: An integrative framework. J. Acad. Mark. Sci. 2004, 32, 3-19. [CrossRef]

43. Stubbs, W.; Cocklin, C. Conceptualizing a "sustainability business model". Organ. Environ. 2008, 21, $103-127$. [CrossRef]

44. Hastings, G.; Domegan, C. Social Marketing: From Tunes to Symphonies, 2nd ed.; Routledge: Abingdon, UK, 2014.

45. Vătămănescu, E.-M.; Andrei, A.G.; Nicolescu, L.; Pînzaru, F.; Zbuchea, A. The Influence of Competitiveness on SMEs Internationalization Effectiveness. Online versus Offline Business Networking. Inf. Syst. Manag. 2017, 34, 205-219. [CrossRef]

46. Vătămănescu, E.-M.; Alexandru, V.-A.; Gorgos, E.-A. The Five Cs Model of Business Internationalization (CMBI) - A preliminary theoretical insight into today's business internationalization challenges. In Strategica. Management, Finance, and Ethics; Brătianu, C., Zbuchea, A., Pînzaru, F., Vătămănescu, E.-M., Eds.; Tritonic: Bucharest, Romania, 2014; pp. 537-558.

47. Beachcroft-Shaw, H.; Ellis, D. Social marketing to achieve sustainability. In Collective Creativity for Responsible and Sustainable Business Practice, 1st ed.; Fields, Z., Ed.; IGI Global: Hershey, PA, USA, 2017; pp. $296-314$.

48. Bratianu, C.; Bolisani, E. Knowledge Strategy: An Integrated Approach for Managing Uncertainty. In Proceedings of the 16th European Conference on Knowledge Management (ECKM 2015), Udine, Italy, 3-4 September 2015; Massaro, M., Garlatti, A., Eds.; Academic Conferences and Publishing International Limited: Reading, UK, 2015; pp. 169-177.

49. Gabler, C.B.; Panagopoulos, N.; Vlachos, P.A.; Rapp, A. Developing an environmentally sustainable business plan: An international B2B case study. Corp. Soc. Responsib. Environ. Manag. 2016, 24, 261-272. [CrossRef]

50. Domingo, L.; Buckingham, M.; Dekoninck, E.; Cornwell, H. The importance of understanding the business context when planning eco-design activities. J. Ind. Prod. Eng. 2015, 32, 3-11.

51. Bocken, N.M.P.; Rana, P.; Short, S.W. Value mapping for sustainable business thinking. J. Ind. Prod. Eng. 2015, 32, 67-81. [CrossRef]

52. Zerwas, C.; Von Korflesch, H.F.O. A conceptual model of entrepreneurial reputation from a venture capitalist's perspective. Int. J. Entrep. Innov. 2016, 17, 143-154. [CrossRef]

53. Tollin, K.; Christensen, L.B.; Wilke, R. Sustainability in business from a marketing perspective. J. Strateg. Mark. 2015, 23, 471-496. [CrossRef]

54. Sharafizad, J. Determinants of relationship marketing by women small business owners. J. Small Bus. Entrep. 2017, 29, 271-291. [CrossRef]

55. Costello, A.B.; Osborne, J. Best practices in exploratory factor analysis: Four recommendations for getting the most from your analysis. Pract. Assess. Res. Eval. 2005, 10, 1-9.

56. Hair, J.F.; Ringle, C.M.; Sarstedt, M. From the Special Issue Guest Editors. J. Mark. Theory Pract. 2011, 19, 135-138.

57. Henseler, J.; Dijkstra, T.K.; Sarstedt, M.; Ringle, C.M.; Diamantopoulos, A.; Straub, D.W. Common beliefs and reality about PLS comments on Rönkkö and Evermann (2013). Organ. Res. Meth. 2014, 17, 182-209. [CrossRef] 
58. Henseler, J.; Ringle, C.M.; Sinkovics, R.R. The use of partial least squares path modeling in international marketing. Advan. Intern. Mark. 2009, 20, 277-320.

59. Chin, W.W. How to write up and report PLS analyses. In Handbook of Partial Least Squares: Concepts, Methods and Applications in Marketing and Related Fields; Esposito Vinzi, V., Chin, W.W., Henseler, J., Wang, H., Eds.; Springer: Berlin, Germany, 2010; pp. 655-690.

60. Henseler, J.; Ringle, C.M.; Sarstedt, M. Using partial least squares path modeling in international advertising research: Basic concepts and recent issues. In Handbook of Research in International Advertising; Okazaki, S., Ed.; Edward Elgar: Cheltenham, UK, 2012; pp. 252-276.

61. Ringle, C.M.; Wende, S.; Becker, J.-M. SmartPLS 3. Boenningstedt: SmartPLS GmbH. 2015. Available online: http: / / www.smartpls.com (accessed on 16 July 2017).

62. Hair, J.F.; Hult, G.T.M.; Ringle, C.M.; Sarstedt, M. A Primer on Partial Least Squares Structural Equation Modeling (PLS-SEM); Sage Publication: Los Angeles, CA, USA, 2014.

63. Barclay, D.; Higgins, C.; Thompson, R. The Partial Least Squares (Pls) Approach to Causal Modeling: Personal Computer Adoption and Use as an Illustration. Technol. Stud. 1995, 2, 285-309.

64. Chin, W.W. The partial least squares approach to structural equation modeling. In Modern Methods for Business Research; Marcoulides, G.A., Ed.; Lawrence Erlbaum: Mahwah, NJ, USA, 1998; pp. 295-358.

65. Fornell, C.; Larcker, D.F. Evaluating structural equation models with unobservable variables and measurement error. J. Mark. Res. 1981, 18, 39-50. [CrossRef]

66. Diamantopoulos, A.; Siguaw, J.A. Formative versus Reflective Indicators in Organizational Measure Development: A Comparison and Empirical Illustration. Br. J. Manag. 2006, 17, 263-282. [CrossRef]

67. Harman, H.H. Modern Factor Analysis; University of Chicago Press: Chicago, IL, USA, 1960.

68. Cohen, J. Statistical Power Analysis for the Behavioral Sciences; Lawrence Erlbaum: Mahwah, NJ, USA, 1988.

69. Sarstedt, M.; Henseler, J.; Ringle, C.M. Multi-group analysis in partial least squares (PLS) path modeling: Alternative methods and empirical results. Adv. Int. Mark. 2011, 22, 195-218.

70. Schubring, S.; Lorscheid, I.; Meyer, M.; Ringle, C.M. The PLS agent: Predictive modeling with PLS-SEM and agent-based simulation. J. Bus. Res. 2016, 69, 4604-4612. [CrossRef]

(C) 2017 by the authors. Licensee MDPI, Basel, Switzerland. This article is an open access article distributed under the terms and conditions of the Creative Commons Attribution (CC BY) license (http:/ / creativecommons.org/licenses/by/4.0/). 